\title{
Front Matter: Volume 8748
}

, "Front Matter: Volume 8748," Proc. SPIE 8748, Optical Pattern Recognition XXIV, 874801 (29 April 2013); doi: 10.1117/12.2022013

SPIE Event: SPIE Defense, Security, and Sensing, 2013, Baltimore, Maryland, SPIE. United States 


\section{PROCEEDINGS OF SPIE}

\section{Optical Pattern Recognition XXIV}

David Casasent

Tien-Hsin Chao

Editors

29-30 April 2013

Baltimore, Maryland, United States

Sponsored and Published by

SPIE 
The papers included in this volume were part of the technical conference cited on the cover and title page. Papers were selected and subject to review by the editors and conference program committee. Some conference presentations may not be available for publication. The papers published in these proceedings reflect the work and thoughts of the authors and are published herein as submitted. The publisher is not responsible for the validity of the information or for any outcomes resulting from reliance thereon.

Please use the following format to cite material from this book:

Author(s), "Title of Paper," in Optical Pattern Recognition XXIV, edited by David Casasent, TienHsin Chao, Proceedings of SPIE Vol. 8748 (SPIE, Bellingham, WA, 2013) Article CID Number.

ISSN: 0277-786X

ISBN: 9780819495396

Published by

SPIE

P.O. Box 10, Bellingham, Washington 98227-0010 USA

Telephone +1 3606763290 (Pacific Time) · Fax +1 3606471445

SPIE.org

Copyright (C) 2013, Society of Photo-Optical Instrumentation Engineers.

Copying of material in this book for internal or personal use, or for the internal or personal use of specific clients, beyond the fair use provisions granted by the U.S. Copyright Law is authorized by SPIE subject to payment of copying fees. The Transactional Reporting Service base fee for this volume is $\$ 18.00$ per article (or portion thereof), which should be paid directly to the Copyright Clearance Center (CCC), 222 Rosewood Drive, Danvers, MA 01923. Payment may also be made electronically through $\mathrm{CCC}$ Online at copyright.com. Other copying for republication, resale, advertising or promotion, or any form of systematic or multiple reproduction of any material in this book is prohibited except with permission in writing from the publisher. The CCC fee code is $0277-786 \mathrm{X} / 13 / \$ 18.00$.

Printed in the United States of America.

Publication of record for individual papers is online in the SPIE Digital Library.

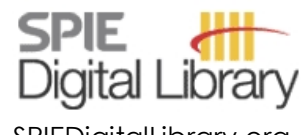

SPIEDigitalLibrary.org

Paper Numbering: Proceedings of SPIE follow an e-First publication model, with papers published first online and then in print and on CD-ROM. Papers are published as they are submitted and meet publication criteria. A unique, consistent, permanent citation identifier (CID) number is assigned to each article at the time of the first publication. Utilization of CIDs allows articles to be fully citable as soon as they are published online, and connects the same identifier to all online, print, and electronic versions of the publication. SPIE uses a six-digit CID article numbering system in which:

- The first four digits correspond to the SPIE volume number.

- The last two digits indicate publication order within the volume using a Base 36 numbering

system employing both numerals and letters. These two-number sets start with 00, 01, 02, 03, 04, $05,06,07,08,09,0 A, 0 B \ldots 0 Z$, followed by 10-1Z, 20-2Z, etc.

The CID Number appears on each page of the manuscript. The complete citation is used on the first page, and an abbreviated version on subsequent pages. Numbers in the index correspond to the last two digits of the six-digit CID Number. 


\section{Contents}

vii Conference Committee

\section{SESSION 1 INVITED OPTICAL PATTERN RECOGNITION PAPERS}

874803 High-speed optical correlator with custom electronics interface design (Invited Paper) [8748-2]

T.-H. Chao, T. T. Lu, Jet Propulsion Lab. (United States)

874804 Light-driven robotics for nanoscopy (Invited Paper) [8748-3]

J. Glückstad, D. Palima, Technical Univ. of Denmark (Denmark)

\section{SESSION 2 QUANTUM AND NUMERIC FFT AND CORRELATOR HARDWARE AND ARCHITECTURES}

874806 Coherent optical implementations of the fast Fourier transform and their comparison to the optical implementation of the quantum Fourier transform [8748-5]

R. C. D. Young, P. M. Birch, C. R. Chatwin, Univ. of Sussex (United Kingdom)

874807 Adapted all-numerical correlator for face recognition applications [8748-6]

M. Elbouz, ISEN Brest (France); F. Bouzidi, ISEN Brest (France) and Univ. of Sfax (Tunisia);

A. Alfalou, ISEN Brest (France); C. Brosseau, Univ. Européenne de Bretagne, Univ. de Brest, Lab-STICC, CNRS (France); I. Leonard, ISEN Brest (France); B.-E. Benkelfat, Institut Télécom, Télécom Sud Paris, CNRS (France)

874808 Robust 3D reconstruction using LiDAR and $\mathbf{N}$ - visual image [8748-22]

P. Duraisamy, Massachusetts Institute of Technology (United States); S. Jackson,

K. Namuduri, Univ. of North Texas (United States); M. S. Alam, Univ. of South Alabama

(United States); B. Buckles, Univ. of North Texas (United States)

\section{SESSION 3 DISTORTION INVARIANT CORRELATION FILTERS}

874809 Smart pattern recognition (Invited Paper) [8748-9]

A. Alfalou, ISEN Brest (France); C. Brosseau, Univ. de Brest, Lab-STICC, CNRS (France);

M. S. Alam, Univ. of South Alabama (United States)

8748 OB Optimized fusion method based on adaptation of the RMS time-frequency criterion for simultaneous compression and encryption of multiple images [8748-11] M. Aldossari, A. Alfalou, ISEN Brest (France); C. Brosseau, Univ. Européenne de Bretagne, Univ. de Brest, Lab-STICC, CNRS (France) 
8748 OD A new morphology algorithm for shoreline extraction from DEM data [8748-13]

A. H. Yousef, K. Iftekharuddin, M. Karim, Old Dominion Univ. (United States)

\section{SESSION 5 PATTERN RECOGNITION APPLICATIONS I}

8748 OG Defining properties of speech spectrogram images to allow effective pre-processing prior to pattern recognition [8748-16]

M. Al-Darkazali, R. Young, C. Chatwin, P. Birch, Univ. of Sussex (United Kingdom)

$8748 \mathrm{OH} \quad$ An image hiding method based on cascaded iterative Fourier transform and public-key encryption algorithm [8748-17]

B. Zhang, J. Sang, Chongqing Univ. (China); M. S. Alam, Univ. of South Alabama (United States)

$8748 \mathrm{Ol} \quad$ Joint Transform Correlation for face tracking: elderly fall detection application [8748-18] P. Katz, M. Aron, A. Alfalou, Institut Supérieur de l'Electronique et du Numérique (France)

$8748 \mathrm{JJ} \quad$ Human gait recognition by pyramid of HOG feature on silhouette images [8748-19]

G. Yang, Y. Yin, J. Park, H. Man, Stevens Institute of Technology (United States)

8748 OK Enhanced information security employing orthogonal code, steganography, and joint transform correlation [8748-20]

M. N. Islam, Farmingdale State College, SUNY (United States); M. F. Islam, George Washington Univ. (United States); K. Shahrabi, Farmingdale State College, SUNY (United States)

SESSION 6 PATTERN RECOGNITION APPLICATIONS II

$8748 \mathrm{OL}$ Optical image processing and pattern recognition algorithms for optimal optical data retrieval [8748-21]

B. Walker, Georgia Institute of Technology (United States); T. Lu, Jet Propulsion Lab. (United States); S. Stuart, Santa Monica College (United States); G. Reyes, T.-H. Chao, Jet Propulsion Lab. (United States)

$87480 \mathrm{M}$ Small feature recognition of moving targets [8748-23]

A. Sokolnikov, Visual Solutions and Applications (United States)

POSTER SESSION: DISTORTION INVARIANT CORRELATION FILTERS

8748 ON Comparison of correlation peaks characteristics for scaled images recognition using MACE, GMACE and MINACE filters [8748-25]

P. A. Ivanov, Yaroslavl State Technical Univ. (Russian Federation)

$874800 \quad$ MINACE filter realization as computer generated hologram for 4-f correlator [8748-26] N. N. Evtikhiev, D. V. Shaulskiy, E. Yu. Zlokazov, R. S. Starikov, National Research Nuclear Univ. MEPhl (Russian Federation) 
8748 OP Distortion invariant correlation filters application for quality inspection of master-matrix for security holograms [8748-27]

E. Zlokazov, D. Shaulskiy, R. Starikov, National Research Nuclear Univ. MEPhl (Russian Federation); S. Odinokov, A. Zherdev, V. Koluchkin, I. Shvetsov, Bauman Moscow State Technical Univ. (Russian Federation); A. Smirnov, Krypten Research and Production Co. (Russian Federation)

$8748 \mathrm{OQ}$ Efficient mine detection using wavelet PCA and morphological top hat filtering [8748-28] N. U. Chowdhury, M. S. Alam, Univ. of South Alabama (United States)

8748 OR JTC based concealed object detection in terahertz imaging [8748-29] M. U. Habib, M. S. Alam, W. K. Al-Assadi, Univ. of South Alabama (United States)

8748 OS Dim small target detection based on stochastic resonance [8748-30]

N. Sang, Huazhong Univ. of Science and Technology (China); R. Wang, Wuhan Univ. (China); H. Gan, J. Du, Q. Tang, Huazhong Univ. of Science and Technology (China)

POSTER SESSION: NOVEL IMAGE PROCESSING TECHNIQUES

8748 OT Spectral fringe-adjusted joint transform correlation based efficient object classification in hyperspectral imagery [8748-31]

P. Sidike, M. S. Alam, Univ. of South Alabama (United States)

Author Index 
Proc. of SPIE Vol. $8748874801-6$

Downloaded From: https://www.spiedigitallibrary.org/conference-proceedings-of-spie on 26 Apr 2023 Terms of Use: https://www.spiedigitallibrary.org/terms-of-use 


\title{
Conference Committee
}

\author{
Symposium Chair
}

Kenneth R. Israel, Major General (USAF Retired) (United States)

Symposium Cochair

David A. Whelan, The Boeing Company (United States)

Conference Chairs

David Casasent, Carnegie Mellon University (United States)

Tien-Hsin Chao, Jet Propulsion Laboratory (United States)

Conference Program Committee

Mohammad S. Alam, University of South Alabama (United States)

Don A. Gregory, The University of Alabama in Huntsville (United States)

Bahram Javidi, University of Connecticut (United States)

B. V. K. Vijaya Kumar, Carnegie Mellon University (United States)

Yunlong Sheng, Université Laval (Canada)

Robert C. Stirbl, Jet Propulsion Laboratory (United States)

Ashit Talukder, National Institute of Standards and Technology (United States)

Rupert C. Young, University of Sussex (United Kingdom)

Session Chairs

1 Invited Optical Pattern Recognition Papers

David Casasent, Carnegie Mellon University (United States)

2 Quantum and Numeric FFT and Correlator Hardware and Architectures

Tien-Hsin Chao, Jet Propulsion Laboratory (United States)

3 Distortion Invariant Correlation Filters

Rupert C. Young, University of Sussex (United Kingdom)

Mohammad S. Alam, University of South Alabama (United States)

$4 \quad$ Novel Image Processing Techniques

Mohammad S. Alam, University of South Alabama (United States) 
5 Pattern Recognition Applications I

Rupert C. Young, University of Sussex (United Kingdom)

Mohammad S. Alam, University of South Alabama (United States)

$6 \quad$ Pattern Recognition Applications II

Tien-Hsin Chao, Jet Propulsion Laboratory (United States)

Rupert C. Young, University of Sussex (United Kingdom) 